\title{
CARVED ISLAMIC CALIGRAPHY IN PALEMBANG: INTERACTION STUDY OF RELIGIOUS VALUE AND LOCAL WISDOM
}

\author{
Husni Mubarat \\ Indo Global Mandiri University Palembang, Indonesia \\ Husni_dkv@uigm.ac.id
}

\begin{abstract}
This study is aimed at examining the interaction of religious values and local wisdom on carving Islamic calligraphy in Palembang. In addition, this study is also aimed at analyzing the interaction of forms and philosophies of carving, physical functions, aesthetic functions, and socio-cultural functions. The benefits of this research include, being able to know how the interaction of religious values and local wisdom on carving Islamic calligraphy in Palembang, can provide motivation for the community to uphold the values of the holy book of the Koran, and can introduce the traditional carvings of Palembang to the wider community. This study uses a qualitative method with a multi-disciplinary approach, such as communication, aesthetics, and socio-culture. The research results achieved are; the interaction of religious values and local wisdom in the carvings are intertwined with mutually adapting harmony, calligraphic forms, decorative forms, and golden colors as characteristic of Palembang's local colors and physical, aesthetic and socio-cultural functions in Islamic calligraphy engraving in Palembang.
\end{abstract}

Keywords: Local Wisdom; Carving, Islamic Calligraphy.

\begin{abstract}
Abstrak
Penelitian ini bertujuan untuk menelaah interaksi nilai religi dan kearifan lokal pada ukiran kaligrafi Islam di Palembang. Selain itu, penelitian ini juga bertujuan untuk menganalisis interaksi bentuk dan filosofi ukiran, fungsi fisik, fungsi estetik, dan fungsi sosio-budaya. Adapun manfaat penelitian ini di antaranya adalah, dapat mengetahui bagaimana interaksi nilai religi dan kearifan lokal pada ukiran kaligrafi Islam di Palembang, dapat memberi
\end{abstract}


motivasi bagi masyarakat untuk menjunjung tinggi nilai-nilai kitab suci Al Quran, dan dapat mengenalkan ukiran tradisional Palembang kepada masyarakat luas. Penelitian ini menggunakan metode kulitatif dengan pendekatan multi disiplin, seperti komunikasi, estetika, dan sosio-budaya. Hasil penelitan yang dicapai adalah; interaksi nilai religi dan kearifan lokal pada ukiran tersebut terjalin dengan harmoni yang saling beradaptasi, bentuk khat kaligrafi, bentuk-bentuk ragam hias, dan warna keemasan sebagai ciri khas warna lokal Palembang serta fungsi fisik, estetik dan fungsi sosio-budaya pada ukiran kaligrafi Islam di Palembang.

Kata Kunci : Kearifan Lokal; Ukiran, Kaligrafi Islam.

Accepted : April 25, 2020 Reviewed: May 6, 2020 Published: June 1, 2020

\section{Introduction}

Artwork is a form that has the values of beauty. Not all people can create works of art, because the creation of a work of art requires talent and sensitivity to a high sense of aesthetics. In addition to being able to give birth to beautiful works of art, an artist (art creator) is also expected to be able to give meaning, concepts, and philosophies so that the artwork can become a medium of communication between artists and the public.

Art activity is a way for artists to communicate their intentions to the audience, for example poets writing poetry, declamators or poetry readers recite poems, musicians or singers sing music and sing messages through music and songs, and painters who visualize the contents of their hearts through brush strokes or pens so that can be understood by connoisseurs of his work (Kusrianto, 2009).

The language of communication can be expressed in various ways, both through visual and non visual. Forms of visual communication can be through carving, dancing, and calligraphy art. While non-visual forms of communication can be through audio (music, magu, speech, or lecture (Budyastomo, 2018).

Furthermore communication is a mechanism that causes human relations and which develops all symbols of thought, which are conveyed through the medium of the media to broadcast it (Sanyoto, 2006).

Referring to the above quotation, it can be interpreted that every work of art must have elements of communication, both in the form of images and in the form of texts, such as in works of art (painting, 
sculpture, and crafts). Communication on artworks can be individualized messages can also be universal, such as traditional wood-based art and religious carving.

The art of calligraphy is also called khat art, is one of Islamic art that developed along with the development of the Islamic world itself. This development has given birth to many styles and styles of khat in accordance with the time and place where the art of khat was growing and developing, especially in the Middle East as a center for the development of the Islamic religion. However, before the time of the Prophet Muhammad the Arabs were not very familiar with writing, because the arts and culture that developed were literary arts that were more synonymous with spoken language.

Arabic calligraphy as a medium of communication for Arabs in particular and Muslims in general, only grew and developed in the middle of the Arab community at the time of the Prophet Muhammad, when the Prophet Muhammad received the first revelation, Surah al-Alaq verses 1-5 (Kemenang RI, 2020) which means "Read in the name of your Lord who created. Creating humans from a clot of blood. Read and your Lord is glorious. Which teaches with a pen. Teaches humans what they don't know".

The revelation is an order of the obligation to read and write for Muslims. This revelation can of course also be interpreted as a form of communication between Allah SWT and the Prophet Muhammad through the angel Gabriel as the messenger or revelation. Starting from this revelation Muslims began to be motivated to write, especially among the companions of the Prophet Muhammad, they began to write and copy the Qur'an and the traditions as a way of life for Muslims throughout the world. Along with this slowly Islamic calligraphy began to grow and develop and was popular in the midst of Islamic society.

A side from being a medium of communication, Islamic calligraphy began to be taken into account as a work of art that has elements of beauty, such as the shape and pattern of lines, some were developed with unisex geometric lines that were developed with curved lines.

The development and spread of Islam throughout the world has had an influence on the style and style of Islamic calligraphy. The influence is inseparable from the cultural factors behind the community. As explained 
(Yudoseputro, 1986) in the book Introduction to Islamic Fine Arts in Indonesia, that in the 14th century recorded a number of Arabic calligraphic styles in accordance with Arabic script created in each region, such as the style of Baghdad, Pharisees, Andalusians, and Istanbul. Regional style in calligraphy is also caused by the stability of the form of characters in each region.

In Indonesia, Islamic caligraphy art does not give birth to the complexion or style of the khat as explained by Yudoseputro above. The complexion or style of calligraphy in Indonesia is more on the media and its application techniques. The art of calligraphy in Indonesia is applied to various media such as metal media, batik cloth, knitting, and wood carving. Especially the art of wood carving calligraphy, each region has its own characteristics in accordance with the cultural and artistic conditions that grow in the area, such as in Palembang, South Sumatra.

Islamic religion spread to various corners of the world, in addition to carrying the teachings of the Qur'an and Hadith, as well as various patterns of civilization, culture, and art. In spreading it, when entering local cultural or artistic areas, it is not uncommon to require compromise by its spreaders (Subana \& Sudrajat, 2005).

One of the art craft that breathes Islam in Palembang is carving Islamic calligraphy. Carved Islamic calligraphy in Palembang was originally in the Palembang Sultanate. If observed, the development of Islamic calligraphy wood carving is not like the development of other wood carving arts, such as carving cabinets, tables and chairs. This factor may be caused by the needs and functions of the work in the midst of community life. Islamic calligraphy carving works are only made for the needs of houses of worship such as mosques and mushalla.

This can be seen in the houses of people in Palembang, where rarely found wall hangings with Palembang Islamic calligraphy carvings. These factors can be said as a result of the lack of design development carried out by carving craftsmen in Palembang.

Unlike Islamic calligraphy engraving in Jepara which developed calligraphy wood carvings into objects that have functions as wall clocks and wall hangings. If the design of calligraphy wood carvings in Palembang could be developed, it might be an alternative for wood 
carving craftsmen to support the economic value of their families in the midst of declining consumer interest in Palembang carving furniture.

A part from the above problems, Islamic calligraphy engraving in Palembang actually has its own uniqueness compared to Islamic calligraphy engraving from other regions, especially Java (Jepara). Islamic calligraphy carvings in Palembang have a very strong style with local characteristics as in the aspects of color, frame, decoration, carving techniques and materials used.

These elements are contained in cultural values which are then combined with Islamic values that can present unique and aesthetic, ethical and cultural values and religious values. The complexity of these values gives birth to the interaction of local religious and cultural values into a harmonious whole and adapt to each other so that they do not conflict with each other.

The uniqueness and peculiarity of Islamic calligraphy wood carving art in Palembang is a manifestation of wood carving art works that are of religious and aesthetic value and framed with local wisdom of the local culture. This interaction illustrates the pattern of religious Palembang community life.

Therefore, the concept is the focal point for the authors in this study. It is hoped that in the future this research can become a scientific paper that can provide knowledge and insight to the community, especially in the city of Palembang and can inspire the community, especially craftsmen to be able to develop Islamic calligraphy carving designs in Palembang with local wisdom patterns, so that the engraving can attract interest Public.

\section{Research Method}

The method used is descriptive qualitative research method. This research method is supported by several theoretical approaches as a scalpel to reveal aspects of the object of research, both visual and nonvisual aspects.

Approach is defined as ways that seem relatively standard, used in various disciplines, such as: emic-ethical, form-content, intrinsicextrinsic, and form-function-meaning (Ratna, 2016). The approach used is a descriptive approach, interpretation, aesthetic theory, and form 
theory, thus the research process can run systematically and organized and able to answer the problems in the research.

\section{Research location}

This research was conducted in various locations, including : (a) Palembang Grand Mosque, Jendral Sudirman Street $19^{\text {st }}$ Ilir, Bukit Kecil, Palembang City. (b) South Sumatera Province. Bayt Al Quran Al Akbar Museum, M. Amin Fauzi, Soak Bujang Street, RT 03, RW 01, Gandus Village, Gandus District, Palembang City. South Sumatera Province. (c) Bala Putra Dewa Museum, South Sumatra, Sriwijaya I Street Km. 5, 5 No. 288, District. Alang-Alang Lebar, Palembang City. South Sumatera Province.

\section{Data Analysis Method}

According Moleng (Moleong, 2017) data analysis is the process of organizing data and sorting data into basic patterns, categories and description units so that themes can be found and work hypotheses can be formulated as suggested by the data.

Data analysis is carried out with several stages, namely, 1) collecting data that has been obtained through observation, interviews, and documentation, 2) selecting data that has been collected based on needs and then discarding data that is considered unnecessary, 3) presentation of data by describing the shape and visual object of the research and interpreting and construing in accordance with the theoretical approach used, 4) formulating conclusions from the research process to presenting data in the form of sentence texts, pictures / schemes, and tables that are presented, then drawn conclusions temporarily. Validation is done by triangulating data, namely from informants, Islamic calligraphy wood carvings, and documentation.

\section{Results and Discussion}

Analysis of Islamic Calligraphy Art Pattern in Palembang is a development of research that has been done before, namely Aesthetic Study of Al Qur'an Wood Carving. As an effort to develop from previous 
research, the Islamic Calligraphy Pattern Analysis in Palembang describes the influence of local wisdom on the form of calligraphy art in Palembang with a multi-disciplinary approach, such as form, function, and aesthetic values.

\section{Elements of Communication in Carving Islamic Calligraphy in Palembang}

In communicating the value of art, artists realize their ideas in the form of art objects to be accepted by others (Sumarjo, 2000). The basis and conditions of acceptance are the socio-cultural context. Because the socio-cultural conditions can change in its development, the value of the same can also change.

As the author has explained in the introduction, the existence of carving Islamic calligraphy in Palembang not only reflects the values of beauty, but also becomes a medium of expression for artists in realizing their creative ideas and ideas. In addition, the element that is no less important is as a medium that can communicate meanings, messages and values that are beneficial to society.

The elements of communication that can be explored in Islamic calligraphy wood carving in Palembang include: (1) Element of Islamic Religion. Of course the elements of communication of religious value are none other than the verses of the Qur'an and the Hadith as the source of the creation of calligraphy engraving. The Qur'an and the Hadith as known by Muslims is a legacy left by the Prophet Muhammad as a guide to life in living a good life of worship, community, culture, and other human activities. The carved verses of the Koran not only function as a display, but also function as a propaganda media so that people can glorify and practice the meaning and message of the contents of the $\mathrm{Al}$ Qur'an and Hadith, such as kursi verses, surah Al Falaq, Asmaul Husna and the other Quran verses. (2) Elements of Local Wisdom. This aspect is closely related to visual cultural identity, namely; color, decoration (carving motif), as well as media and cultivation techniques. These elements provide an overview of Palembang's traditional values, such as carving motifs that illustrate the harmony of society with nature, the environment and how humans maintain relationships with the creator of 
the universe. In addition, this element also communicates how strong the aesthetic values that exist in the craft, such as the composition and linkages of motifs that are united with each other to form a harmonious rhythmic pattern. An equally important aspect is historical value. The decorative carvings in the Islamic calligraphy carvings in Palembang provide insights into the culture of the traditional traditions of the past, which certainly need to be maintained and developed so that they are always sustainable from time to time so that they can be studied by the next generation. (3) Element of Expression. This element shows how the effort and creativity of artists gave birth to Islamic calligraphy carvings in Palembang. Of course, this effort is not all people can do it. In addition to the beautiful work, which can provide entertainment and calm for the people who appreciate it, this work also provides motivational value to the community, namely the encouragement to uphold the holy book of the Qur'an as a guide to life in the world towards the hereafter.

\section{Interaction of Calligraphy Form and Philosophy in Palembang Local Culture Scope}

The form in the analysis of Palembang Islamic Calligraphy Wood Carving in the Frame of Local Wisdom is defined as a physical form that can be seen, both the calligraphy, color, texture, and media used. Overall, Palembang Islamic calligraphy carvings are in the form of twodimensional panels carved from Tembesu wood. Tembesu wood material itself is a wood plant that grows a lot in the Southern Sumatra region, especially South Sumatra. This wood forms its own characteristics as Palembang carving art as Jepara carving carved from teak wood.

The form in the context of woodcraft is a physical form. Beauty that has very many perspectives and almost every art expert gives a meaning that is sometimes very subjective. However, almost all opinions point to the issue of giving meaning and aesthetics to the connoisseur of beauty. The phrase can be interpreted that the form of wood carving is inseparable from the aesthetic elements that surround it. Through form, a wood carving work of art can be observed how the elements of the work form a balance, harmony, unity and proportion so that the work can be enjoyed by the public. 
Talking about the form in art, especially Palembang Islamic calligraphy wood carving, actually cannot be separated from the meaning and philosophy behind the form of the work. The physical formulation and philosophical meaning are very closely related to the background factors of the supporting community both the belief system, social and cultural.

The art of Palembang Islamic calligraphy carving, physically not only exudes elements of beauty, but also carries religious and cultural values. Religious value is certainly related to the media of da'wah which is the content of the Holy Qur'an to be conveyed to humanity about the truth of the teachings of Islam. Besides that Palembang Islamic calligraphy carvings also reflect religious communities, as the slogan is Palembang Darussalam. In terms of cultural values, Palembang Islamic calligraphy has its own style and character as well as craft art in other regions, which have their own local characteristics, both in color, carving motifs and the materials used.

The unity of form and meaning behind it is an element that has a reciprocal relationship so that it can produce works of art that are beneficial to the audience, both physically and the message and meaning that it conveys, as expressed (Kartika, 2007), that there are two kinds of forms: first visual form, which is the physical form of a work of art or a unity of the supporting elements of the work of art, the second is a special form, which is a form that is created due to a reciprocal relationship between the values emitted by physical form phenomena to the response of emotional awareness.

With regard to these elements, the elements of shape which surround Palembang calligraphy wood carvings can be described as follows: (1) Calligraphy, if observed as a whole, Islamic calligraphy in Palembang uses a type of khat that already exists or is commonly used in general calligraphic writing, namely the Naskhi script with a very clear reading value and a formal form, but still displays beautiful forms. Calligraphy engraving in Palembang also uses Tsuluts type of khat, but this type of khat is only used in certain parts (short passages) that prioritize the beauty of khat. In accordance with the history of the development of Islamic calligraphy itself, where the art of calligraphy that grew in the archipelago is the adoption of calligraphy that already exists, both 
calligraphy style of Baghdad, the Pharisees, Andalusians, and Istanbul with various types of khat. With regard to form, as for the differentiator of the form of calligraphy in Palembang is the type of media and techniques used.

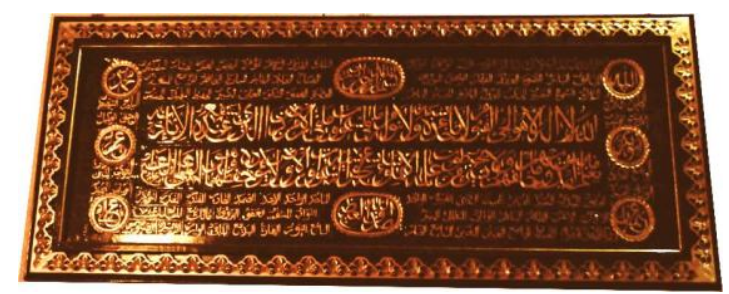

Figure 1. One of the Islamic Calligraphy Wood Carvings in the Bayt Al Quran Al Akbar Palembang. This Carving Is Decorated With Jasmine Flower Motifs. (Source: Author, 2018)

Almost all Islamic calligraphy carvings in Palembang use medium wood with carving techniques and filigree. This also distinguishes the style of Palembang Islamic calligraphy engraving with other regions in Indonesia such as Islamic calligraphy engraving in Jepara. (2) Color, as for the color used is gold. The gold color itself is the color that is always used in every Palembang wood carving including Islamic calligraphy engraving. The golden color for the people of Palembang is a color that has been attached from time to time, with a great philosophy, majestic and thick with Islamic nuances, so that the color has its own place in Palembang's local handicrafts, especially wood carvings. This golden color, usually combined with mahogany brown as a background color and not infrequently also combined with a reddish brown color. (3) Variety of Ornament, according to (Soegeng, 2000) explains that the variety of decoration is present in the midst of people's lives as a media for expressing feelings that are manifested in a visual form, the process of its creation is inseparable from environmental influences. It is intended as a complement to aesthetic taste. 


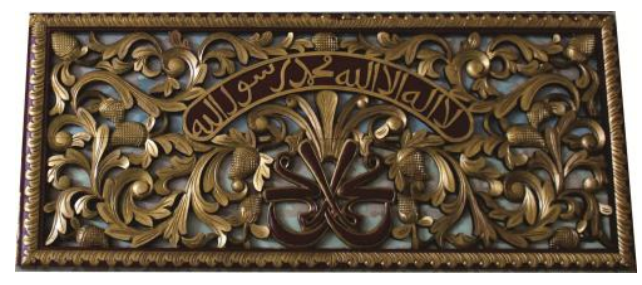

Figure 2. Calligraphy wood carving; one of the collections of the Museum of Bala Putra Dewa, South Sumatra, with Motifs of Lines and Noni Fruit. This carving is thought to originate from the Sultanate of Palembang Darussalam (Source: Author, 2018).

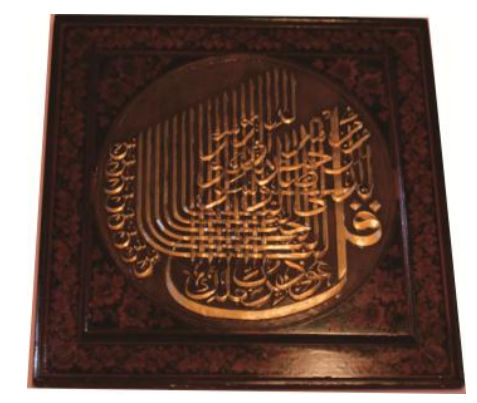

Figure 3. One of the Islamic calligraphy wood carvings found in Bayt Al Quran Al Akbar Palembang. Carving motifs on the edges are made with laker painting techniques, with rose flower motifs and leaf tendrils. (Source: Author 2018).

As for the decoration that is used in the form of plant motifs and tendrils, as found in Palembang carvings in general, and not infrequently Palembang calligraphy carvings are combined with laker decorative painting techniques. Laker itself is a traditional Palembang craft which is a cultural heritage of the past. Laker painting techniques are usually applied to the frame of calligraphy carvings with a combination of gold and black. As revealed (Suryanegara et al., 2007) that traces of the influence of Islamic civilization in South Sumatra, especially in fine arts and more specifically in decoration can be found to spread throughout the region. The influence was aesthetically undergoing a process of renewal (acculturation) with teachings that were first held by people in South Sumatra, such as Hindu-Buddhism. In subsequent developments, the teachings of Islamic Islam have influenced the dimensions of mysticism, spiritualism, theology in almost all works of art, especially fine art (decoration). The fact of this influence can be found in the 
tendency of the play of decorative motifs in South Sumatra, which prefers flora (plants) over fauna (animals) and humans.

Table 1. Types of Palembang Motifs

\begin{tabular}{lll}
\hline No & \multicolumn{1}{c}{ Motif name } & \multicolumn{1}{c}{ Symbol of motifs } \\
1. & Kembang Tanjung & Symbol of Welcome \\
2. & Jasmine Flower & Symbol of Custom Courtesy \\
3. & Rose Flower & Symbol of the Bidder \\
4. & Red and White Lotus & Symbol of Purity \\
& Flower &
\end{tabular}

It can be understood that the existence of decoration in Palembang Islamic calligraphy carvings is not only as a complement to the sense of beauty, but also upholds the meaning behind its form, both related to social values, culture, and religious values.

\section{Interaction of Calligraphy Carving Function as Artwork}

The function intended in the analysis of Islamic calligraphy wood carving crafts in Palembang is not only related to the physical aspects, but also related to social functions, aesthetic functions and cultural functions that exist in the work. Namely: (1) Physical Functions, carving Islamic calligraphy in Palembang physically function as a pentilation (wind hole), as can be seen in the Palembang Grand Mosque, where a portion of the mosque pentilation is made with Islamic calligraphy engraving. Besides functioning as a pentilation, calligraphy engraving in Palembang also functions as a room divider for prayer between men and women. Physically, the form of carving usually follows its physical functions, such as window pentilation, carvings are made with filigree carving (translucent carving) techniques, while in other parts such as drum and some in the field of calligraphy carvings carved with medium carving techniques. (2) Aesthetic function, carving Islamic calligraphy in Palembang serves as the mosque's interior decoration. Aesthetically, Islamic calligraphy engraving in Palembang is usually applied to some interior furniture, such as sermons, panels and drum. The presence of calligraphy in the interior media not only gives an Islamic identity, but can also create these forms more beautiful, so that if observed, the interior 
media can not only feel physical function, but also can provide a beautiful sense for the community (worshipers mosque) so that it can increase the love of the Islamic community towards the Qur'an and its carving caligraphy. In addition, the aesthetic function of Islamic calligraphy in Palembang is also an ornamental art carved in the form of panels. Usually these panels are displayed in office spaces or at home. This is not only intended as a beautifying room, but also as a sign that a Muslim loves the reading and writing of the Qur'an. (3) Social functions, Islamic calligraphy carving in Palembang as a medium for da'wah for the people to know and love the Qur'an as the Muslim holy book. Carving of Islamic calligraphy also shows a religious community, so that it hopes to increase people's understanding of the contents of the Qur'an. Another social function is as a means for the community to recognize and maintain local culture, namely Palembang carving patterns. Another social function is as a means of science, through this calligraphy engraving the public can get to know and add insight into Palembang wood carving art, especially in the context of Islamic Calligraphy art.

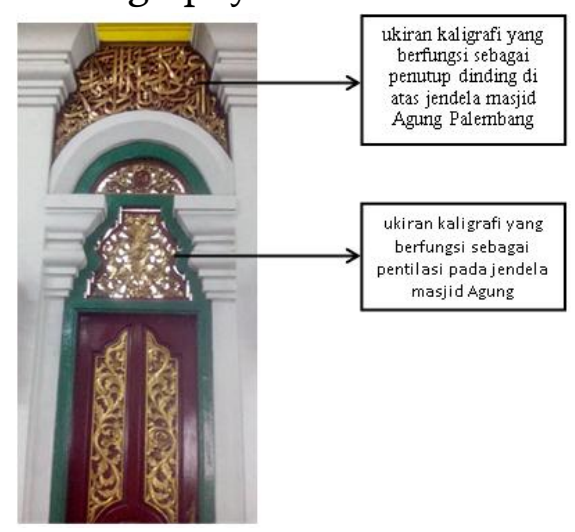

Figure 4. One of the Islamic calligraphy wood carvings found in the Bayt Al Quran Al Akbar Palembang. Carving motifs on the edges are made with laker painting techniques, with rose flower motifs and leaf tendrils.

(Source: Muksin Ilhaq, 2019).

\section{Conclusion}

The elements of communication in Islamic calligraphy carving in Palembang are interactions of religious values and local wisdom. The 
interaction of values adapts to each other, so that there is a unified harmony that cannot be separated from the meaning and philosophy and the aesthetic values that surround it.

The style of Islamic calligraphy in Palembang is a work of carving that has aesthetic value, is unique and has its own character when compared to calligraphy engraving in other areas. The locality values that can be observed in Islamic calligraphy carvings in Palembang are the variety of decoration, color, type of material used, and the engraving technique applied. The carving motifs used are leaf vine motifs and flower motifs such as jasmine flowers, roses, sunflowers and noni fruit motifs. The color used is gold color combined with red and brown as the background color of the engraving. The golden color itself is a characteristic of Palembang's locality color.

In terms of function, the engraving of Islamic calligraphy in Palembang has a physical function (as a pentilation in the window), an aesthetic function (as a room decorating religious values), and a social function (as a media for da'wah and scientific means of calligraphy art insight).

The unity of form, meaning, philosophy, and the value of the function behind the carving are elements that have a reciprocal relationship, so that they are able to produce works of art that are useful and can be communicated to the audience, both physically and the message and meaning they convey.

When observed as a whole, there are still some weaknesses that exist in the calligraphy engraving, one of which is the development of designs that still seem monotonous and formal as a rectangular shape (panel). Forms like this should be developed further into other square shapes (octagon) and circle and ellipse shapes. In addition to form, aspects of the function of carving Islamic calligraphy in Palembang, it should also be developed into products such as wall clocks, mirror frames, and decorative lamp shades, so as to encourage the emergence of a creative economy in it.

The existence of Islamic calligraphy wood carving in Palembang, should be recognized as a work of art that contributes to enrich the treasures of local culture and fine arts in Indonesia, particularly Islamic art. Therefore, it is expected that the results of this study can contribute to 
the insight of fine arts in Indonesia. The hope is that Islamic calligraphy wood carvings in Palembang can be recognized by the wider community and can be developed into works that are communicative, dynamic, aesthetic, and religious values and framed with local wisdom, so that it can become an industry and creative economy.

\section{Bibliography}

Budyastomo, A. W. (2018). BATOBOH Jurnal Pengabdian Pada Masyarakat Bentuk Bahasa Komunikasi Dalam Seni Grafiti Sebagai Media Penyampaian Pesan (Studi Kasus: Padepokan Grafiti Salatiga). Jurnal Batoboh, 3 (2 Oktober 2018), 146-156. https://doi.org/http://dx.doi.org/10.26887/bt.v3i2.527

Kartika, S. D. (2007). Kritik seni (A. Pandanwangi (ed.); 1st ed., Vol. 1). Bandung: Rekayasa Sains.

Kemenang RI. (2020). Al-'Alaq - $\square \square \square$. Kemenag Republik Indonesia. https://quran.kemenag.go.id/sura/96

Kusrianto, A. (2009). Pengantar Desain Komunikasi Visual. In P. Desa (Ed.), Pengantar Desain Komunikasi Visual (1st ed., Vol. 1). Yogyakarta: Andi Offset.

Moleong, A. J. (2017). Metodologi Penelitian Kualitatif (Edisi Revisi). Bandung: Remaja Rosdakarya.

Ratna, N. K. (2016). Metodologi Penelitian : Kajian Budaya dan Ilmu Sosial Humaniora Pada Umumnya (1st ed., Vol. 1). Yogyakarta: Pustaka Pelajar.

Sanyoto, S. E. (2006). Metode Perancangan Komunikasi Visual Perikalan (H.

Wijanarto (ed.); 1st ed., Vol. 1). Dimensi Press. Soegeng, T. M. (2000). Mengenal Ragam Hias Indonesia (3rd ed., Vol. 1). Yogyakarta: Angkasa.

Subana, M., \& Sudrajat. (2005). Dasar-Dasar Penelitian Ilmiah (1st ed., Vol. 1). Bandung: Pustaka Setia.

Sumarjo, Y. (2000). Filsafat seni (1st ed.). Bandung: Penerbit ITB.

Suryanegara, E., Damayanti, N., \& Yudoseputro, W. (2007). Artifak Purba Pasemah: Analisis Ungkap Rupa Patung Megalitik di Pasemah. ITB Journal of Visual Art and Design, 1(1), 128-151. https://doi.org/10.5614/itbj.vad.2007.1.1.9 
Yudoseputro, W. (1986). Pengantar Seni Rupa Islam di Indonesia (1st ed., Vol. 1). Bandung: Angkasa. 